\title{
Suitable Wind Turbine Selection using Evaluation of Wind Energy Potential in IRAN
}

\author{
Hadi Sefidgar $^{1}$ and S. Asghar Gholamian ${ }^{2}$ \\ 1,2Babol University of Technology, Faculty of Electrical and Computer Engineering, \\ Babol, Iran
}

\begin{abstract}
Nowadays, low environmental impact of wind energy is attractive. This paper aims to investigate the windpower production potential of sites in North of Iran. Analysis of the wind speed of one city in the province of MAZANDARAN which is located in north of Iran is performed in this paper. The class of this site is a class one wind power site and the annual average wind speed is $3.58 \mathrm{~m} / \mathrm{s}$. The power density of this site is $99 \mathrm{~W} / \mathrm{m} 2$ at $50 \mathrm{~m}$ height. Wind speed data measured over a five-year period at a typical site on the north coast of Iran are presented. The annual wind speeds at different heights have been studied to make optimum selection of wind turbine installation among three commercial turbines.
\end{abstract}

\section{Keywords}

Wind turbine, Wind energy potential, Wind power density, MAZANDARAN.

\section{Introduction}

Wind energy is one of the most promising solutions, especially considering its technological advancements and its growth over the past years [2]. Iran is one of the countries which have recently paid a great attention to install and also build wind turbines.

A power wind generator is one of the best and cleanest methods of producing electricity and can be a proper replacement for conventional fossil fuel [3].

Nowadays, the increasing demand for electrical energy and the restriction on pollution levels have led to an increasing interest in large scale utilization of renewable energies like wind and PV across many countries for example Iran. It is known that the supplies of fossil energy (such as oil, gas and ...) are limited and their utilization as energy sources causes' environmental degradation due to incomplete combustion when used as energy source.

In addition to this as the increasing of population increases the demand for energy sources, therefore the issue of a seldom replacement of fossil fuels with renewable energy sources is major consideration for all of countries: Iran Bing (in Asian Middle East) has a great potential for producing about 7000MW of electricity with wind energy [4]. 
Wind has been estimated that about 10 million MW of energy are available in the earth's wind continuously. Electrical energy from wind energy provides a variable and environmental option and national energy security at a time when decreasing global reserves of fossil energies threatens the Long-period sustainability of global economy [5].

Fig. 1 provides further details of the global growth of the wind energy sector [6].

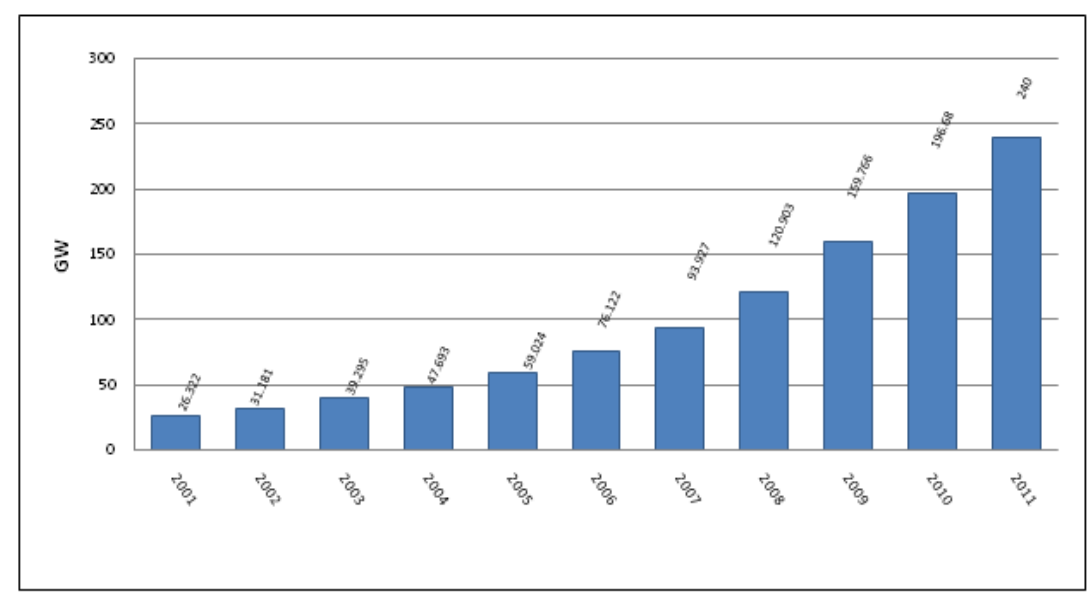

Fig.1. World total installed capacity

Researchers believe the fossil fuel will be seldom at the turn of the 21 st century, and the oil stores would not last for few decades, they find it necessary to study and investigate into the use of everlasting or renewable source of energy like wind, the sun and other sources by the time the energy crisis arrives.

Since there is an infinite cycle of renewable sources such as the wind and the sun all over the country there is an urgent need to use the mentioned sources of energies. The first step to study the feasibility of using the wind energy is to analyze the data from past based upon the wind speed at different elevations. We have studied the feasibility of using the wind in Amirabad Seaport in Mazandaran province by analyzing the speed of the wind and its potential in past 5 years $[6,7]$.

\section{Wind energy in Amirabad Seaport}

Wind speed data are summarized in a number of ways in the literature, including averages and variances, frequency histograms, and theoretical frequency distributions fitted to the data. Weibull distribution is generally considered for representing wind speed variations. The potential of wind energy of a site depends both on wind speeds and the proportion of time for which these speed points are available.

In addition, the air density is the height of the turbine tower. All of these concepts are considered in the following sections. 


\subsection{Wind speed characterization}

The wind speed data used in this research were measured from the stations at a standard height of $10 \mathrm{~m}$. The wind speed at any height can be calculated by equation (1) [1].

$\frac{V(h)}{V_{r}}=\frac{\ln \left(h / h_{0}\right)}{\ln \left(h_{r} / h_{0}\right)}$

$\mathrm{V}(\mathrm{h})=$ the wind speed at the required or extrapolated height $\mathrm{h}$

$V_{r}=$ the reference wind speed at reference height $h_{r}$

$\mathrm{h}_{0}=$ the surface roughness length, which characterizes the roughness of the terrain.

In this research, $\mathrm{h}_{0}$ was calculated from Eq. (1) using the measured speeds at $10 \mathrm{~m}$ height. Equation (1) was then used to estimate wind speeds at $50 \mathrm{~m}$ and $70 \mathrm{~m}$ height, since commercial wind turbines generally have a hub height of $50 \mathrm{~m}$ or more.

The percentage frequency histogram of wind speed for the year is shown in Fig. 2. It can be noted that, the cut-in speed is $3 \mathrm{~m} / \mathrm{s}$ for in site because the wind speed for $70 \%$ of the time in the year is rather $3 \mathrm{~m} / \mathrm{s}$. Therefore, the wind turbine selected would the cut-in speed is $3 \mathrm{~m} / \mathrm{s}$. The cut-out wind speed is commonly $20-25 \mathrm{~m} / \mathrm{s}$ and such speeds are rare at this site. The Weibull probability density function, which is most commonly used to characterize wind speed distribution, calculated by

$f(V)=\left(\frac{k}{c}\right)\left(\frac{V}{c}\right)^{k-1} \exp \left[-\left(\frac{V}{c}\right)\right]$

Where $\mathrm{V}$ is wind speed, $\mathrm{c}$ is a scale factor and $\mathrm{k}$ is a shape factor. To estimate Weibull parameters from speed data using the maximum likelihood method the following equations are used:

$$
\begin{aligned}
& \mathrm{k}=\left(\frac{\sum_{j=1}^{N} V_{j}^{k} \ln \left(V_{j}\right)}{\sum_{j=1}^{N} V_{j}^{k}}-\frac{\sum_{j=1}^{N} \ln \left(V_{j}\right)}{N}\right)^{-1} \\
& \mathrm{c}=\left(\frac{1}{\mathrm{~N}} \sum_{j=1}^{N} V_{j}^{k}\right)^{1 / k}
\end{aligned}
$$

Where, $\mathrm{V}_{\mathrm{j}}$ is the wind speed in time step $\mathrm{j}$ and $\mathrm{N}$ is the number of nonzero wind speed data points. 
International Journal on Cybernetics \& Informatics ( IJCI) Vol.2, No.6, December 2013

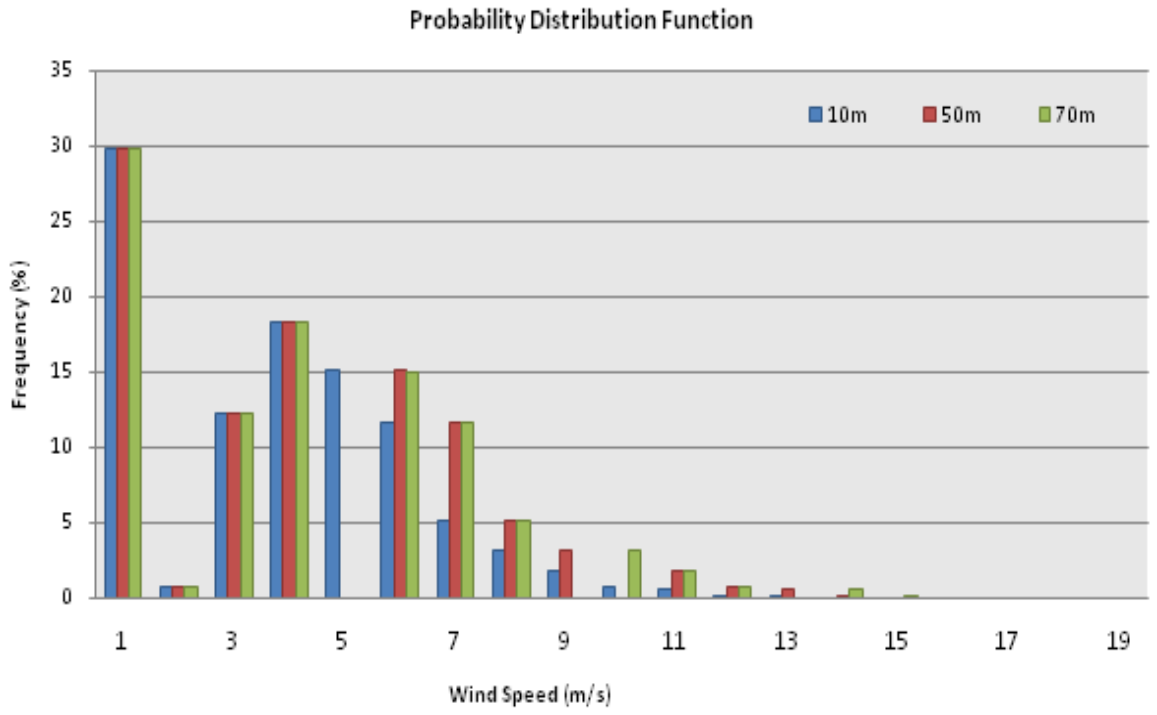

Fig.2. Frequency distribution of wind speed at Amirabad Seaport over the year

Eq. (3) must be solved using an iterative procedure ( $\mathrm{k}=2$ is a suitable initial guess), and then Eq. (4) can be solved for c. Care must be taken to apply Equation (3) only to the nonzero data points of speed

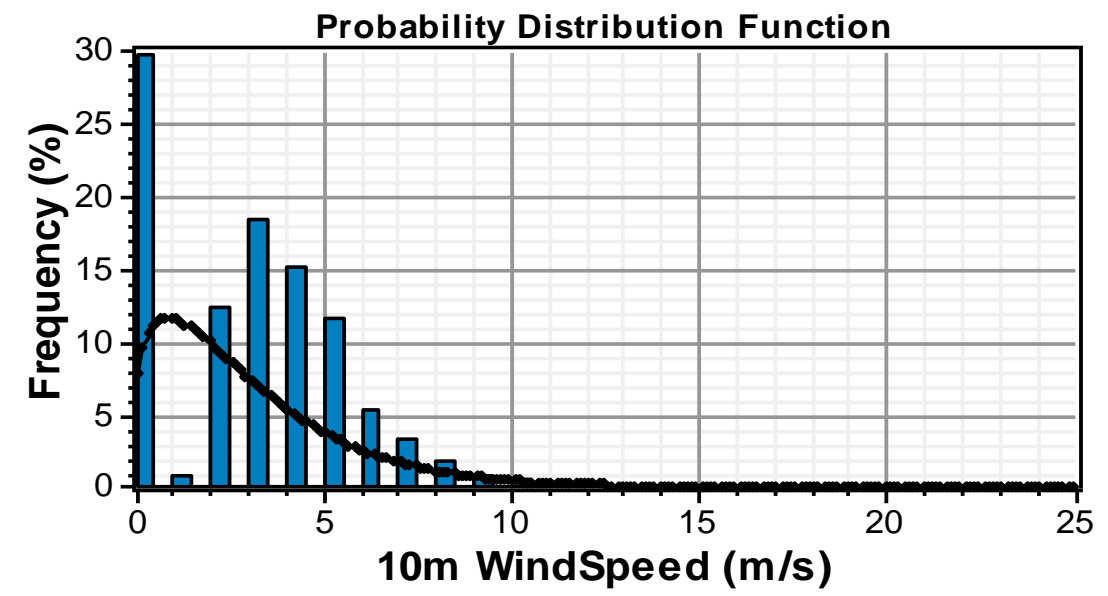

- Actual data - Best-fit Weibull distribution (k=1.23. $\mathrm{c}=3.21 \mathrm{~m} / \mathrm{s})$ 


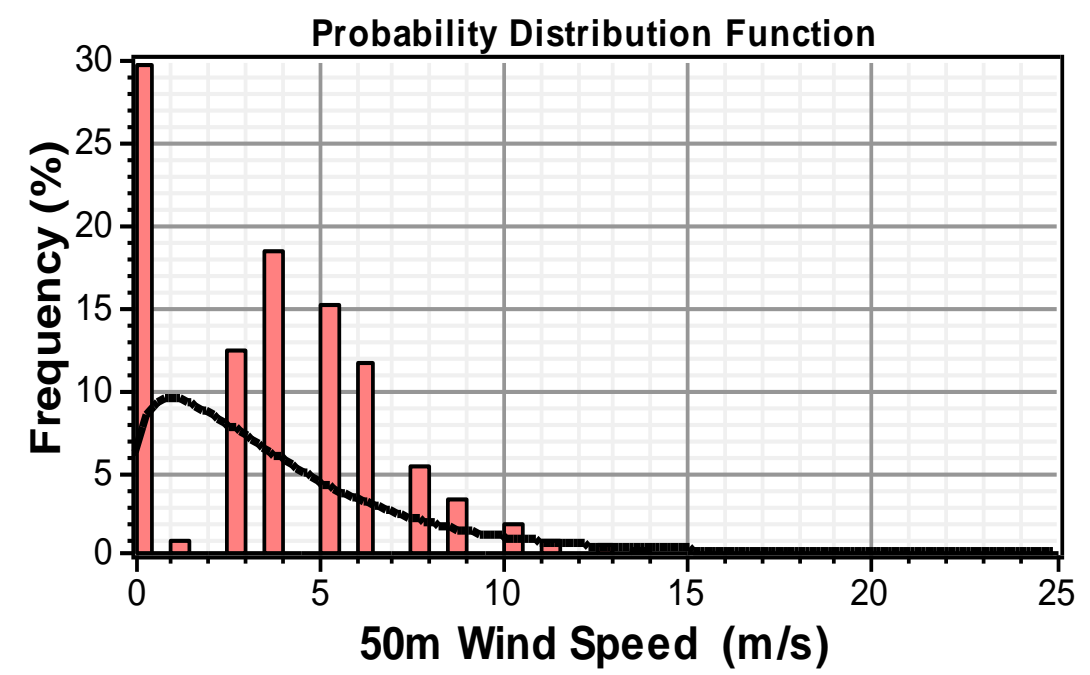

- Actual data - Best-fit Weibull distribution (k=1.23. $c=4.02 \mathrm{~m} / \mathrm{s})$

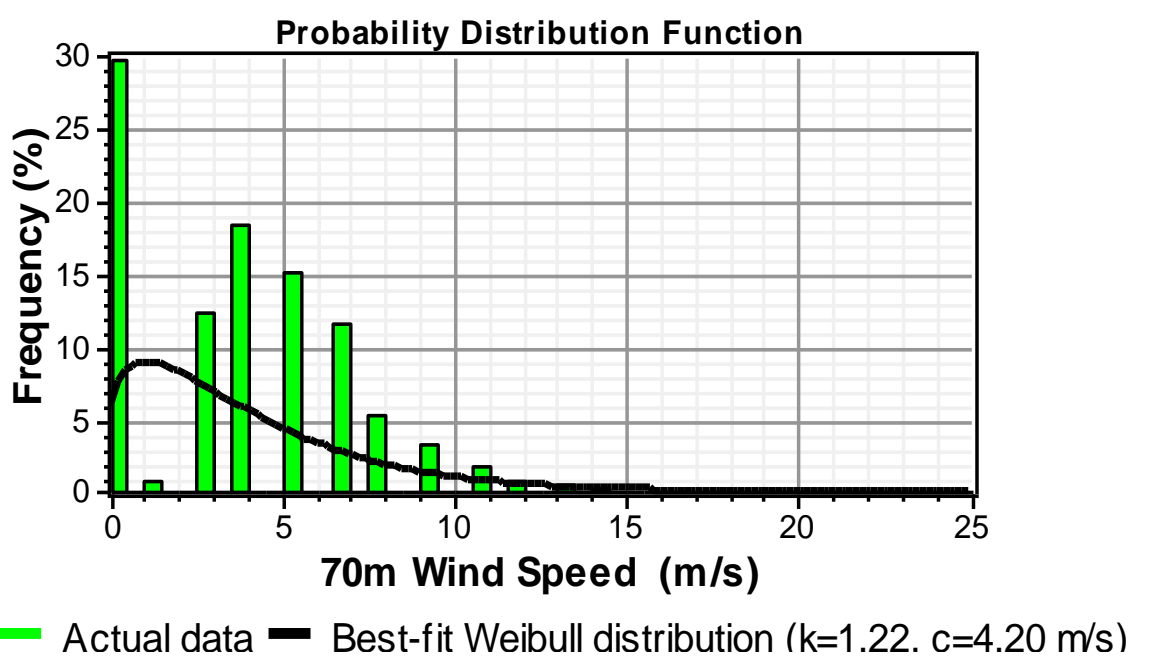

Fig.3. Weibull distributions of wind speeds for different heights at Amirabad Seaport over the year

The Weibull distributions of wind speeds at some heights superposed on the frequency distributions is shown in Fig. 3. The annual average and standard deviation of wind speed, the Weibull parameters, and the average available wind power density (defined below) at different heights are given in Table1. Table 2 and Table 3 shown separate characterization for each month was also carried out. 
International Journal on Cybernetics \& Informatics ( IJCI) Vol.2, No.6, December 2013

Table1. Wind speed parameters at Amirabad Seaport for the year.

\begin{tabular}{|c|c|c|c|c|c|}
\hline & $\begin{array}{c}\text { Wind } \\
\text { speed } \\
(\mathrm{m} / \mathrm{s})\end{array}$ & $\begin{array}{c}\text { Std. Dev } \\
(\mathrm{m} / \mathrm{s})\end{array}$ & $\begin{array}{c}\text { Weibull c } \\
(\mathrm{m} / \mathrm{s})\end{array}$ & Weibull k & $\begin{array}{c}\text { Mean } \\
\left(\mathrm{W} / \mathrm{m}^{2}\right)\end{array}$ \\
\hline $\begin{array}{c}\mathbf{1 0 m} \\
\text { Height }\end{array}$ & 2.86 & 2.4169 & 3.2133 & 1.238 & 50.013 \\
\hline $\begin{array}{c}\mathbf{5 0 m} \\
\text { Height }\end{array}$ & 3.58 & 3.0275 & 4.0214 & 1.234 & 98.322 \\
\hline $\begin{array}{c}\mathbf{7 0 m} \\
\text { Height }\end{array}$ & 3.75 & 3.1737 & 4.1956 & 1.220 & 113.24 \\
\hline
\end{tabular}

The monthly average of wind speeds and power densities are shown in Figs. 4 and 5, respectively. The figures show a large seasonal variation. Wind speeds are higher in the summer season (Jun- Jul) but generally aren't suitable for good power production because, fig. 6 shown the average wind power densities at $50 \mathrm{~m}$ height for 6 years is minor $200 \mathrm{~W} / \mathrm{m}^{2}$ put in class 1 (least energy).

Table2. Wind speed and wind power density at Amirabad Seaport by month

\begin{tabular}{|c|c|c|c|c|c|c|c|c|c|c|c|c|c|}
\hline & & Jan & Feb & Mar & Apr & May & Jun & Jul & Aug & Sep & Oct & Nov & Dec \\
\hline $\begin{array}{c}10 \mathrm{~m} \\
\text { Height }\end{array}$ & $\begin{array}{c}\text { Wind } \\
\text { spd } \\
(\mathrm{m} / \mathrm{s})\end{array}$ & 2.34 & 2.92 & 3.09 & 3.02 & 2.80 & 3.33 & 3.64 & 2.81 & 2.77 & 2.41 & 2.53 & 2.61 \\
\cline { 2 - 11 } & $\begin{array}{c}\text { Mean } \\
\left(\mathrm{W} / \mathrm{m}^{2}\right)\end{array}$ & 35 & 61 & 63 & 59 & 50 & 62 & 72 & 41 & 35 & 31 & 45 & 45 \\
\hline $\begin{array}{c}50 \mathrm{~m} \\
\text { Height }\end{array}$ & $\begin{array}{c}\text { Wind } \\
\text { spd } \\
(\mathrm{m} / \mathrm{s})\end{array}$ & 2.93 & 3.65 & 3.87 & 3.78 & 3.51 & 4.17 & 4.56 & 3.52 & 3.47 & 3.03 & 3.17 & 3.27 \\
\cline { 2 - 11 } & $\begin{array}{c}\text { Mean } \\
\left(\mathrm{W} / \mathrm{m}^{2}\right)\end{array}$ & 69 & 121 & 123 & 117 & 97 & 121 & 142 & 80 & 69 & 61 & 88 & 89 \\
\hline $\begin{array}{c}70 \mathrm{~m} \\
\text { Height }\end{array}$ & $\begin{array}{c}\text { Wind } \\
\text { spd } \\
(\mathrm{m} / \mathrm{s})\end{array}$ & 3.07 & 3.83 & 4.05 & 3.97 & 3.68 & 4.37 & 4.78 & 3.69 & 3.63 & 3.17 & 3.32 & 3.43 \\
\cline { 2 - 11 } & $\begin{array}{c}\text { Mean } \\
\left(\mathrm{W} / \mathrm{m}^{2}\right)\end{array}$ & 80 & 140 & 142 & 135 & 113 & 140 & 164 & 92 & 80 & 70 & 102 & 103 \\
\hline
\end{tabular}


International Journal on Cybernetics \& Informatics ( IJCI) Vol.2, No.6, December 2013

Table3. Wind speed characterization at Amirabad Seaport by month

\begin{tabular}{|c|c|c|c|c|c|c|c|c|c|c|c|c|c|}
\hline & & $\operatorname{Jan}$ & Feb & Mar & Apr & May & Jun & Jul & Aug & Sep & Oct & Nov & Dec \\
\hline \multirow{4}{*}{$\begin{array}{c}10 \mathrm{~m} \\
\text { Height }\end{array}$} & Std. & 2.22 & 2.55 & 2.37 & 2.52 & 3.02 & 2.45 & 2.50 & 2.24 & 2.07 & 2.07 & 2.26 & 2.31 \\
\hline & $\begin{array}{c}\text { Dev } \\
(\mathrm{m} / \mathrm{s})\end{array}$ & & & & & & & & & & & & \\
\hline & $\begin{array}{l}\text { Weibull } \\
\mathrm{c}(\mathrm{m} / \mathrm{s})\end{array}$ & 2.67 & 3.31 & 3.08 & 3.32 & 4.15 & 3.85 & 4.23 & 3.28 & 3.24 & 2.80 & 4.81 & 2.98 \\
\hline & $\begin{array}{c}\text { Weibull } \\
\mathrm{k}\end{array}$ & 1.18 & 1.25 & 1.29 & 1.41 & 1.66 & 1.56 & 1.69 & 1.51 & 1.59 & 1.38 & 2.92 & 1.26 \\
\hline \multirow{4}{*}{$\begin{array}{c}50 \mathrm{~m} \\
\text { Height }\end{array}$} & Std. & 2.78 & 3.19 & 2.97 & 3.16 & 3.02 & 3.07 & 3.13 & 2.81 & 2.60 & 2.59 & 2.83 & 2.89 \\
\hline & $\begin{array}{c}\text { Dev } \\
(\mathrm{m} / \mathrm{s})\end{array}$ & & & & & & & & & & & & \\
\hline & $\begin{array}{l}\text { Weibull } \\
\mathrm{c}(\mathrm{m} / \mathrm{s})\end{array}$ & 3.51 & 4.26 & 4.40 & 4.65 & 4.20 & 4.86 & 5.36 & 4.13 & 4.11 & 3.70 & 6.04 & 3.89 \\
\hline & $\begin{array}{c}\text { Weibull } \\
\mathrm{k}\end{array}$ & 1.30 & 1.34 & 1.73 & 1.55 & 1.44 & 1.59 & 1.77 & 1.53 & 1.65 & 1.53 & 2.93 & 1.38 \\
\hline \multirow{4}{*}{$\begin{array}{c}70 \mathrm{~m} \\
\text { Height }\end{array}$} & Std. & 2.92 & 3.35 & 3.11 & 3.30 & 3.17 & 3.22 & 3.28 & 2.94 & 2.72 & 2.72 & 2.97 & 3.04 \\
\hline & $\begin{array}{c}\text { Dev } \\
(\mathrm{m} / \mathrm{s})\end{array}$ & & & & & & & & & & & & \\
\hline & $\begin{array}{l}\text { Weibull } \\
\mathrm{c}(\mathrm{m} / \mathrm{s})\end{array}$ & 3.65 & 4.44 & 4.58 & 4.85 & 4.44 & 5.08 & 5.61 & 4.32 & 4.30 & 3.85 & 6.31 & 4.09 \\
\hline & Weibull & 1.28 & 1.32 & 1.66 & 1.54 & 1.47 & 1.57 & 1.76 & 1.53 & 1.64 & 1.51 & 2.92 & 1.39 \\
\hline
\end{tabular}

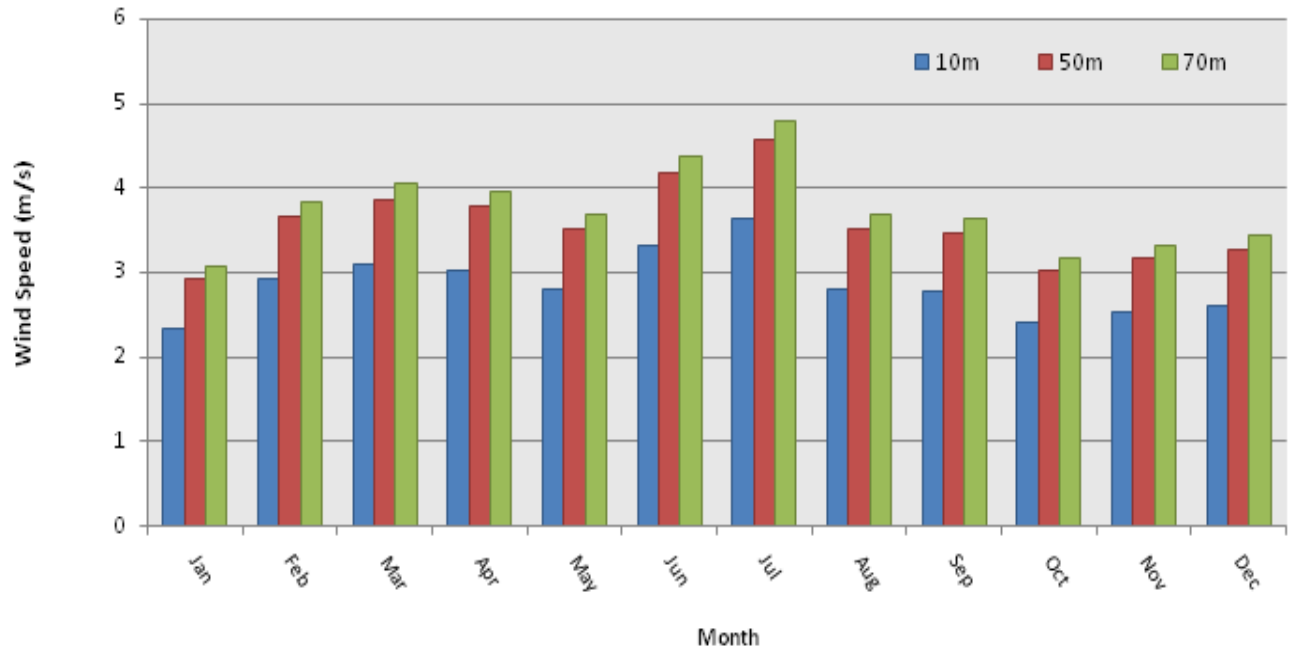

Fig.4. Monthly average wind speeds at $10 \mathrm{~m}, 50 \mathrm{~m}$ and $70 \mathrm{~m}$ heights at AMIRABAD 
International Journal on Cybernetics \& Informatics ( IJCI) Vol.2, No.6, December 2013

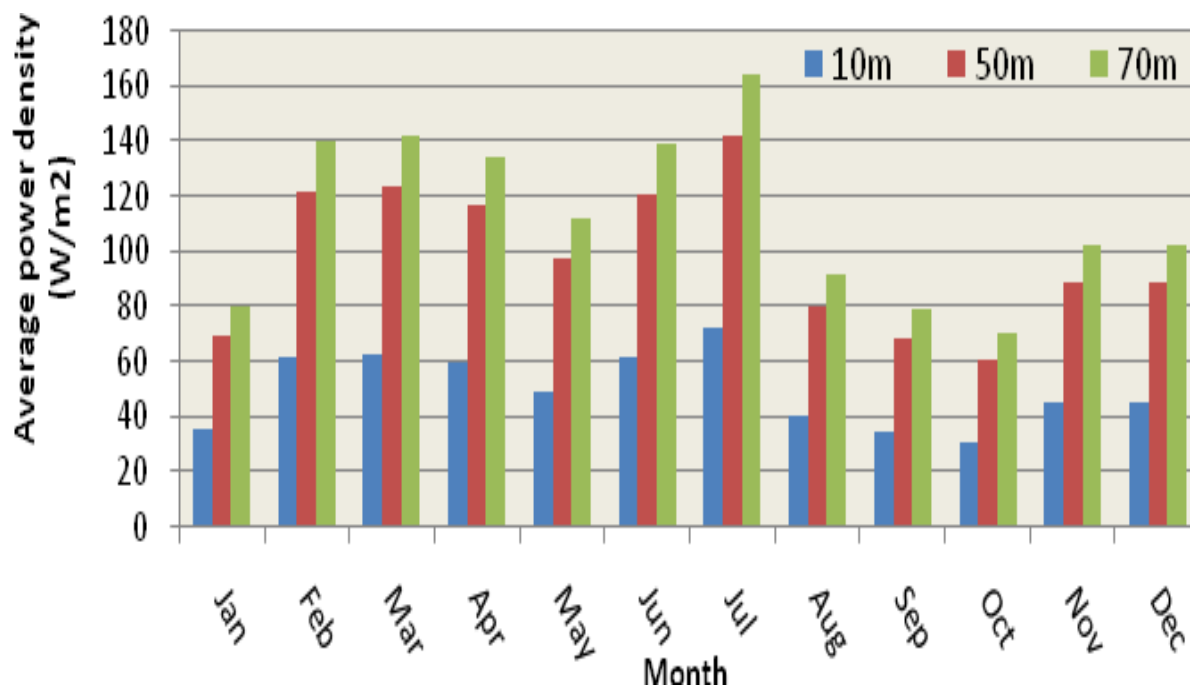

Fig.5. Monthly average power density at $10 \mathrm{~m}, 50 \mathrm{~m}$ and $70 \mathrm{~m}$ at AMIRABAD

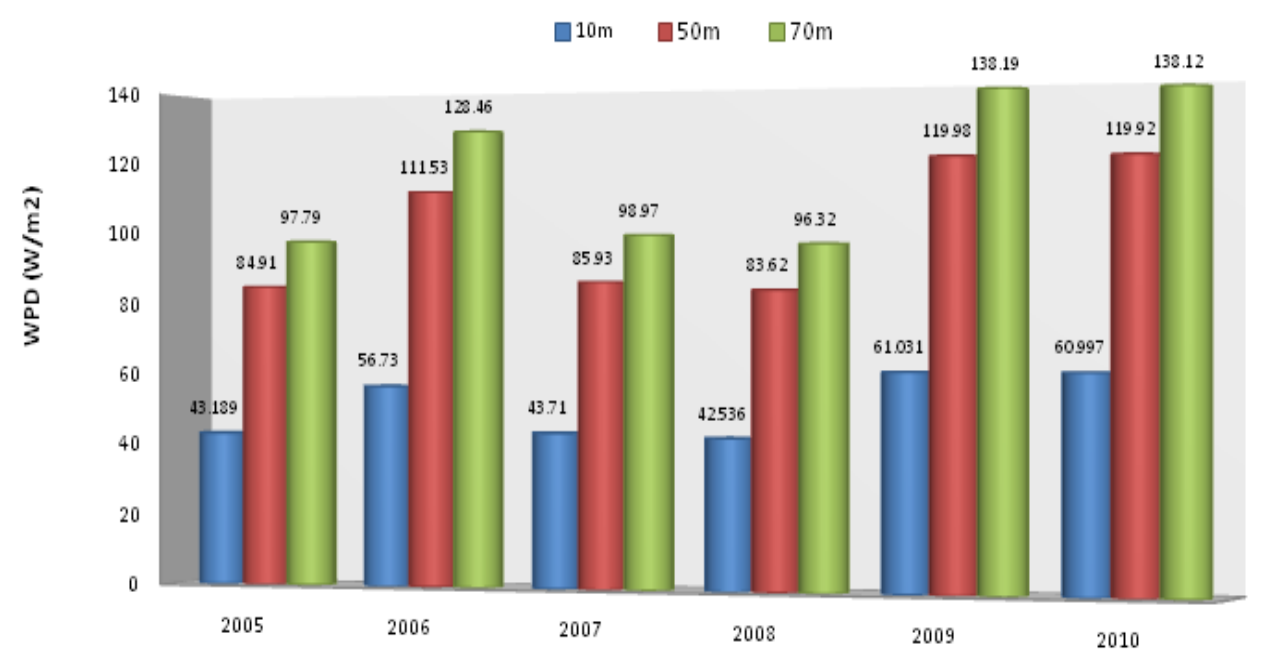

Fig.6. Annual average wind power density at AMIRABAD Seaport for six years

\subsection{Estimation of wind power}

The wind speed distribution is ultimately used to estimate the wind energy output. The power $\mathrm{P}$ in the wind has the cubic relation with the wind speed V. The wind power density E can be described with a wind speed probability density (or distribution) function $\mathrm{f}(\mathrm{V})$.

$P(V)=\frac{1}{3} \rho A V^{3}$ 
$E=\frac{P}{A}=\int_{0}^{\infty} \frac{1}{2} \rho V^{3} f(V) d V=\frac{1}{2} \rho c^{3} T\left(\frac{k+3}{k}\right)$

Where $\rho$ is air density and A is the wind turbine blade sweep area.

Hence, the wind power density distribution can be expressed as follows [7],

$e(V)=\frac{1}{2} \rho V^{3} f(V)$

The wind power density can thus be obtained by integrating the power density distribution in the range from the minimum to the maximum wind speed.

The average power density available over the whole year is found to be $98.32 \mathrm{~W} / \mathrm{m}^{2}$ at $50 \mathrm{~m}$ height for AMIRABAD Seaport. Total available yearly energy density is $862 \mathrm{KWh} / \mathrm{m}^{2}$ of rotor area in AMIRABAD Seaport. The actual power of commercial turbine is expected to produce at this site depends on rotor area, hub height, and the efficiency or capacity factor of the turbine.

\section{Results and discussion}

The USA wind energy atlas defines seven wind power classes to categorize the wind energy resource at a site. The $3.58 \mathrm{~m} / \mathrm{s}$ annual average wind speed and $98.32 \mathrm{~W} / \mathrm{m}^{2}$ average power densities at $50 \mathrm{~m}$ height put Amirabad Seaport in class 1. Since, the wind speeds dispersal is major, between 2 than $3 \mathrm{~m} / \mathrm{s}$ in Amirabad site, impossible utilize high power wind turbines that cut-in speed is further $5 \mathrm{~m} / \mathrm{s}$. therefore is suitable, the low power wind turbines use in site [1].

Commercial wind turbines are designed for high wind sites and do not perform as well in low winds. Turbines designed to take advantage of local wind regimes will capture more energy, thus lowering the cost. The performance curves for the respective machine output are provided in Fig. 7. Table 4 shows the parameters of each wind turbine, including the nominal power, the rotor diameter, the hub height, the rated wind speed, and the cut-in and cut-out speeds of all of wind turbine.

Table 5 shows the average power produced, total energy output over the year, and capacity factor of each turbine for this site. In other to, turbine costs are estimated, using the thumb rule [8] of US $\$ 1000$ per $\mathrm{kWh}$, as $\$ 450,000$. Installation costs are taken as a further $20 \%$ of turbine cost and operation and maintenance as $2 \%$ of turbine cost per year. With a turbine life of 20 years and a real interest rate of $5 \%$, the cost of electricity is calculated as 3.7 cents per $\mathrm{kWh}$ at present day prices. Therefore, with the average wind speed and the average wind power density is available in site and wind turbines characterization that shows in table 5, is suitable until selected wind turbine Proven $/ 15 \mathrm{kw}$. Since, PROVEN wind turbine contains less cost and further capacity factor than other two wind turbine. Hence, the electricity production costs reduce. Fig. 8 shows comparison of generators performance in this study. 
International Journal on Cybernetics \& Informatics ( IJCI) Vol.2, No.6, December 2013
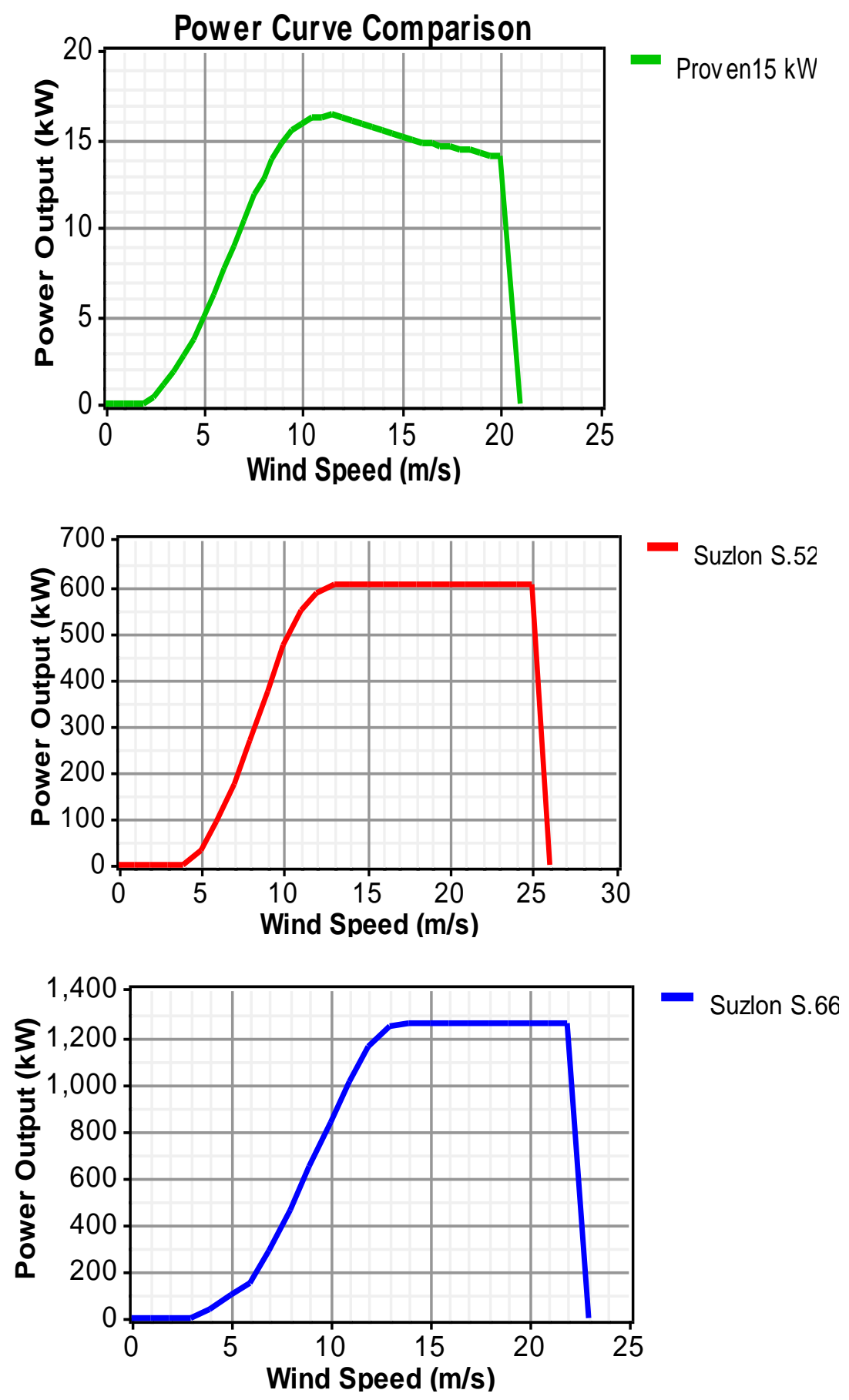

Fig.7. Performance curves for the three wind turbines considered in this study. 
International Journal on Cybernetics \& Informatics ( IJCI) Vol.2, No.6, December 2013

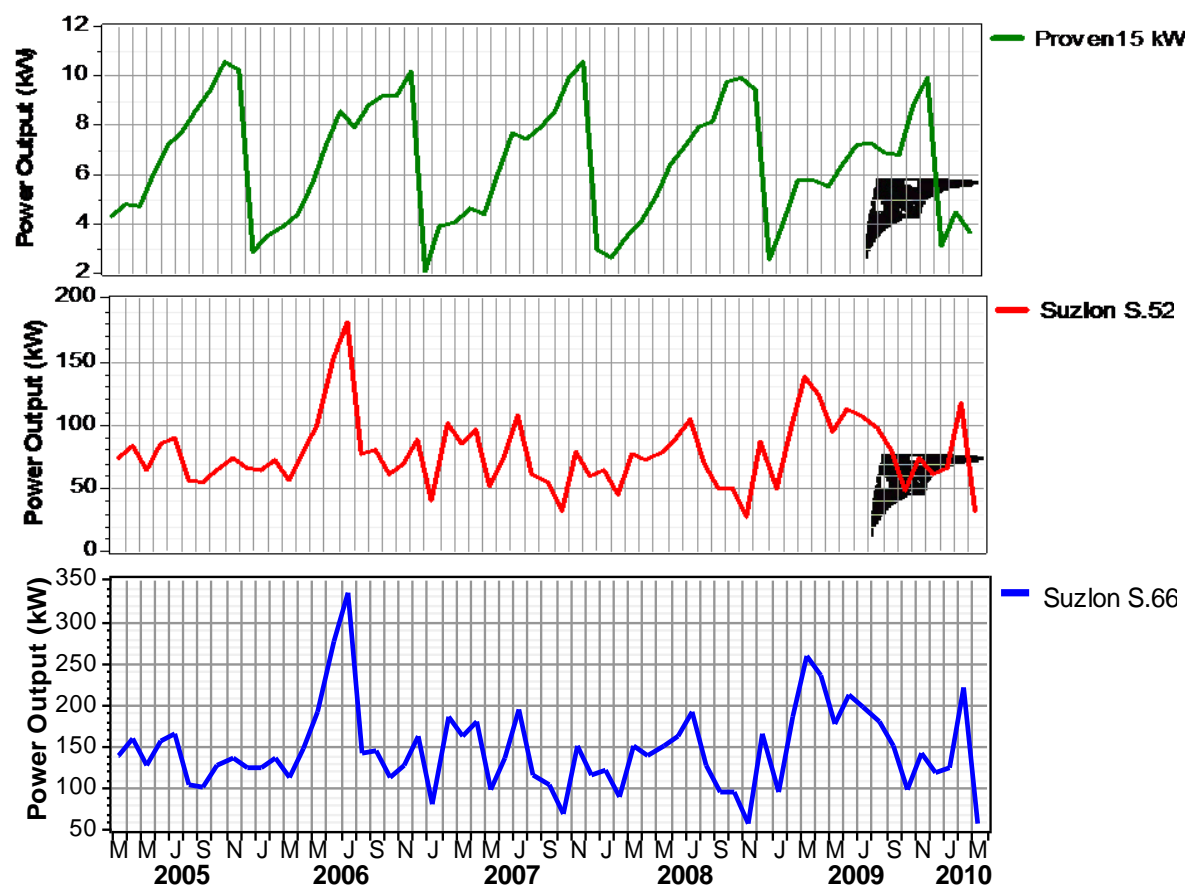

Fig.8. Inter-comparison of machine performance for AMIRABAD, March 2005-March 201

Table4. Parameters of selected wind turbines

\begin{tabular}{|c|c|c|c|}
\hline Turbine model & SUZLON s66 & SUZLONs52 & $\begin{array}{c}\text { PROVEN } \\
15 \mathrm{kw}\end{array}$ \\
\hline Rated power $(\mathrm{kW})$ & 1250 & 600 & 15 \\
\hline Rotor diameter $(\mathrm{m})$ & 66 & 52 & 9 \\
\hline Hub height $(\mathrm{m})$ & 74.5 & 75 & 15 \\
\hline Cut-in wind speed (m/s) & 3 & 4 & 2.5 \\
\hline Rated wind speed (m/s) & 14 & 13 & 9 \\
\hline Cut-out wind speed (m/s) & 23 & 26 & 21 \\
& & & \\
\hline
\end{tabular}


International Journal on Cybernetics \& Informatics ( IJCI) Vol.2, No.6, December 2013

Table5. Expected yearly power production by selected turbines

\begin{tabular}{|c|c|c|c|}
\hline \multirow{2}{*}{} & \multicolumn{3}{|c|}{ Turbine } \\
\cline { 2 - 4 } & $\begin{array}{c}\text { SUZLON } \\
\text { s66 }\end{array}$ & $\begin{array}{c}\text { SUZLON } \\
\text { s52 }\end{array}$ & $\begin{array}{c}\text { PROVEN } \\
15 \mathrm{kw}\end{array}$ \\
\hline $\begin{array}{c}\text { Mean power Output } \\
(\mathrm{kw})\end{array}$ & 115 & 61.3 & 4.3 \\
\hline $\begin{array}{c}\text { Mean Energy Output } \\
\text { (Mwh/yr) }\end{array}$ & 1007 & 537 & 38 \\
\hline Capacity factor & 0.09 & 0.10 & 0.28 \\
\hline
\end{tabular}

\section{Conclusions}

- Wind energy is an attractive choice because of its low impact on environment, sustainability, and reasonable costs. Statistical detail study of wind speed at $10 \mathrm{~m}, 50 \mathrm{~m}$ and $70 \mathrm{~m}$ heights for AMIRABAD in Iran is presented. There are important justifications to be found for advancement different sources of renewable energy in MAZANDARAN such as wind, and solar. This paper used wind speed data over a Period 5 years, to assess the wind power potential at this site.

- An evaluation of the wind resource available at AMIRABAD Seaport on the coast shows that AMIRABAD Seaport have annual average wind speed of less than $4 \mathrm{~m} / \mathrm{s}$ which is considered as undesirable for installation of the wind turbines. The annual wind speeds at different heights have been studied to make optimum selection of wind turbine installation among three commercial turbines.

- Using wind turbine technology can be a suitable choice compared to other sources, but it should be noted that development of wind turbine in Iran is impressive and in the future many suitable areas would become the site for the small or big wind turbine farms.

\section{References}

[1] Irfan U,Gamar -uz-Z, Andrew J; An evaluation of wind energy potential at Kati Seaport, Pakistan'; Elsevier 2010

[2] Pantaleo A. Feasibility study of off-shore wind farms: an application to Puglia region. Sol Energy 2005

[3] Mostafaeipour A, Sadeghian A. Development of wind turbine in Iran. Melbourne, Australia: WWEC; 2005.

[4] Dawud Fadai. The feasibility of manufacturing wind turbines in Iran. Renewable Sustainable Energy Rev 2005.

[5] oselin Herbert GM, et al. A review of wind energy technologies. Renewable and Sustainable Energy Rev 2006.

[6] World Wind Energy Association (WWEA), "World wind energy report 2010", (April 2011).

[7] www.suna.org.

[8] Emami L. Feasibility study of electricity production in Yazd. Iran: Yazd University; 2008.

[9] Ashraf Chaudhry M, Hayat SA, Raza R. Renewable energy technology in Pakistan: prospects and challenges. Melbourne, Australia: WWEC; 2005.

[10] Danish Wind Energy Association.Wind Energy Guided Tour. 